INDEPENDENT JOURNAL OF MANAGEMENT \& PRODUCTION (IJM\&P)

http://www.ijmp.jor.br

v. 12, n. 2, March-April 2021

ISSN: 2236-269X

DOI: 10.14807/ijmp.v12i2.1249

\title{
APPLICATION OF SYSTEM ANALYSIS AND PREVENTIVE MAINTENANCE ON CIGARETTE PACKER LINE
}

\author{
Mohamed fathi karoui \\ University of Carthage, Tunisia \\ E-mail: fathi.karoui@gmail.com \\ Mohamed Najeh Lakhoua \\ University of Carthage, Tunisia \\ E-mail: mohamednajeh.lakhoua@enicarthage.rnu.tn
}

Submission: $1 / 15 / 2020$

Revision: 5/13/2020

Accept: 6/3/2020

\section{ABSTRACT}

The use of system analysis and preventive maintenance in today's industry becomes a necessity as it increases equipment availability. These methods reduce the frequency of failures. The objective of this article is to present a case study for improving the reliability and availability of a production group in an industrial enterprise. Next, we present an improvement in maintenance. Finally, we present and discuss the application of preventive maintenance. Through an industrial manufacturing model, we will combine three tools; SADT modelling, the FMECA analysis and the Pareto diagram to arrive at an optimal maintenance approach that will be a decision support tool in order to minimize the repair costs and the downtime of the system.

Keywords: System analysis; industry; preventive maintenance; SADT; FMECA; Pareto diagram 
DOI: 10.14807/ijmp.v12i2.1249

\section{INTRODUCTION}

The systemic approach, sometimes called systemic analysis, is an interdisciplinary field relating to the study of objects in their complexity. Indeed, it allows the description of a study object in its environment, in its functioning, in its mechanisms and also in the interactions that result from these three aspects (Lakhoua, 2013; Lakhoua, 2011; Lakhoua et al., 2016). The application of system analysis and preventative maintenance allows the industrial company to increase its profit thanks to the reduction of the budget needed for maintenance (Lakhoua, 2018). In order to effectively implement effective preventive maintenance that meets the company needs, it must follow a specific approach that allows knowing first the most critical components of each machine, and then to clear preventive actions related to these components.

In this context, we propose a methodology to improve the reliability and availability of a production system. This methodology consists of three stages; the first consists of a functional analysis by the SADT method, the second in an analysis of failures by the FMECA approach and finally in the prioritization of problems according to the number of their occurrence by the Pareto diagram (Lakhoua et al., 2016; Bareib et al., 2016; Monchy, 2015; Marca, 2012).

\section{PRESENTATION OF A CIGARETTE-MAKING PROCESS}

The purpose of this part is to visualize the main stages of the cigarette manufacturing process (Figure 1). It is a way to understand, analyze, standardize and improve the process (Rocha, 1998). Indeed, diagnosis is an essential step to get a general idea of the current state of the process. Knowing the status will be crucial to better detect failures and causes of malfunctions and will help us to provide effective solutions. To do this, we will initiate our approach by diagnosing the current functioning of the system which will allow us to locate the most critical machine in the manufacturing process (Fakhfakh et al., 2011).

Although our diagnosis was made on all of the factory's production equipment, in our case we will limit the study to cigarette packaging equipment, where there have been frequent stops and a very serious increase in cost during its malfunction, the one hour shutdown cost is equivalent to 60,000 dinars with a very low machine efficiency $\eta=60 \%$ (Malaoui et al., 2017).

The tools used in this work to improve maintenance will then be generalized on all equipment of the plant after confirmation of the expected approach's results. 


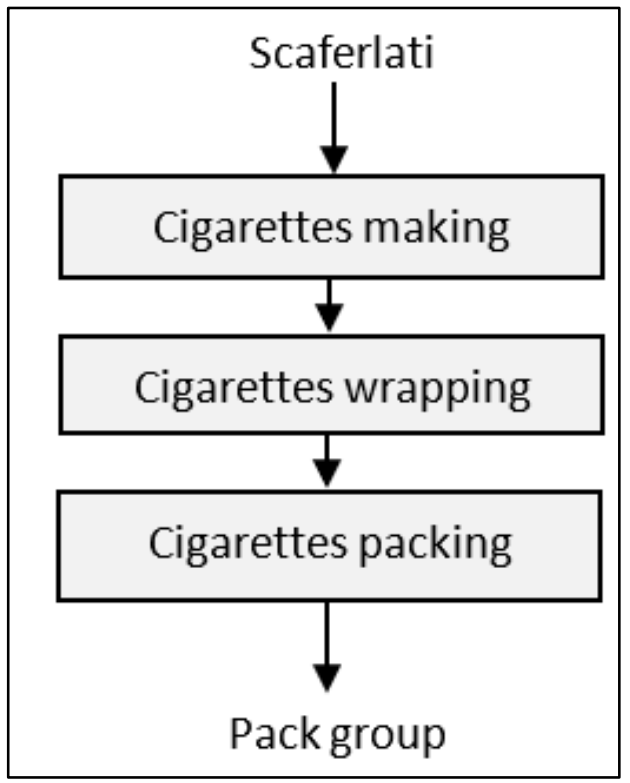

Figure 1: Cigarettes manufacturing process

\section{GENERAL INFORMATION ON MAINTENANCE}

In this section, we will describe the main tools used in this approach. This is why we present the concept of functional analysis by the SADT method, the objectives and the different types of maintenance, as well as the history and interest of the FMECA method, finally the Pareto diagram construction stage (Bassetto, 2005).

According to standards NF X 60-010 and NF X 60-011: Maintenance is the set of actions to maintain or restore a property in a specified state or capable of providing a specified service.

Based on this definition, two different concepts can be distinguished, one referring to a corrective aspect and the other referring to a forward-looking aspect (Vari-Kakas et al., 2015).

The maintenance objectives are (Lakhoua et al., 2011 ; Lakhoua et al., 2018) :

- $\quad$ Reducing the outages frequency;

- Minimizing the duration of downtime due to accidental service interruptions;

- Ensure rigorous and regular monitoring of maintenance performance (dashboard).

There are different types of maintenance according to the NF X 60-000 standard.

Failure can be defined as an alteration or cessation of a property's ability to perform the required function. There are two forms of failure: partial failure which is an alteration or degradation of a property's ability to perform the required function and total failure which is the cessation of a property's ability to perform the required function. 
- Corrective maintenance, sometimes called curative maintenance (a non-standard term), aims to restore equipment to an optimal operating state for use. Various defects, failures or damage requiring corrective maintenance resulting in immediate or very short-term unavailability of the affected equipment and/or a decrease in the quantity and/or quality of the services provided.

- Preventive maintenance: Maintenance performed according to predetermined criteria, the objective of which is to reduce the probability of failure of a good or degradation of a service rendered. This should help prevent hardware failures in use. The cost analysis should show a gain on the failures it avoids. The purpose of preventive maintenance is to: increase the service life of the equipment; reduce the likelihood of service failures; reduce downtime in case of overhaul or failure; Prevent and anticipate costly maintenance interventions. Make a corrective maintenance decision in good conditions; Avoid abnormal consumption of energy, lubricant, spare parts, etc. Improve working conditions of production personnel; reduce maintenance budget; eliminate the causes of serious accidents.

- $\quad$ Systematic Preventive Maintenance: Preventive maintenance performed according to a schedule based on the time or number of units of use (produced). Even if time is the most common unit, other units may be used such as: the quantity of products manufactured, the length of the products manufactured, the distance travelled, the mass of the products manufactured, the number of cycles carried out, etc. Conditional preventive maintenance: Preventive maintenance subject to a predetermined type of event (self-diagnosis, sensor information, wear measurement, etc.). Predictive maintenance is performed based on the evolution of a symptom or degradation for improved reliability, improved maintainability, etc. to evolve to zero failure.

\subsection{SADT method}

Structured Analysis Design Technique (SADT) represents an image of the system (Figure 2). It is a method of analysis to understand the main function of the system, what subfunctions it must perform and finally, how these functions are performed and the degree of their complexity. The method is based on a graphical model. The modelling approach is topdown; from general behavior to detailed operation, focusing on system activity (D. T. Ross, 1977). 
DOI: 10.14807/ijmp.v12i2.1249

The SADT method appears to be suitable for modelling such systems for at least one reason: it applies perfectly to multi-technology systems, that is, it adapts to mechanical, electronic and software systems. But it does not take into account the dynamic aspect of the system.

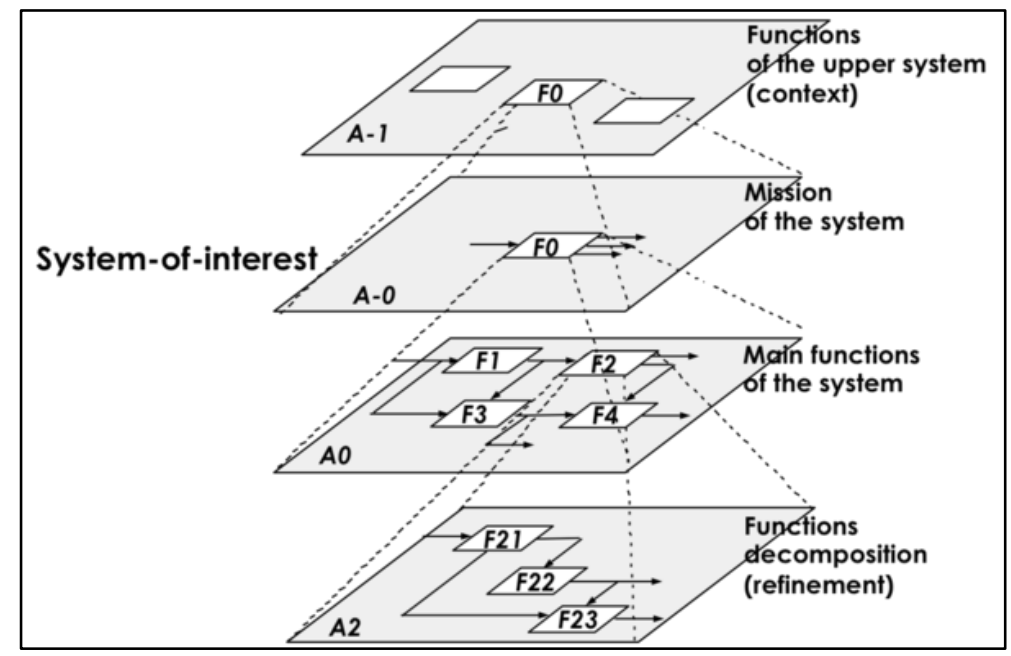

Figure 2: Structure of an SADT model

The boxes called ICOM's input-control-output-mechanisms are hierarchically decomposed. At the top of the hierarchy, the overall purpose of the system is shown, which is then decomposed into components-sub activities. The decomposition process continues until there is enough detail to serve the purpose of the model builder. SADT/IDEF0 models ensure consistency of the overall modelled system at each level of the decomposition

A not too long title should be provided. The title should precisely accomplish the main idea of the paper and must be typed in times new roman, 12, all caps, centered.

\subsection{FMECA}

The method presented in this research relates to failure mode, effects and criticality analysis (FMECA). In fact, this method is an extension of the failure mode and effect analysis (FMEA) (Buzzatto, 1999; Saman, 2017). The FMEA is an inductive upward analysis method that can be performed at the functional level or at the part level. The FMECA expands the FMEA by including a criticality analysis, which is used to represent the probability of failure modes based on the severity of their consequences. The result highlights the failure modes with a relatively high probability and severity of consequences, which helps guide repair efforts where they will produce greater value.

The FMECA analysis procedure typically consists of the following logical steps:

- Define the system; 
DOI: 10.14807/ijmp.v12i2.1249

- Define ground rules and assumptions in order to help drive the design;

- Construct system block diagrams;

- Identify failure modes (piece part level or functional);

- Analyse failure effects/causes;

- Feed results back into design process;

- Classify the failure effects by severity;

- Perform criticality calculations;

- Rank failure mode criticality;

- Determine critical items;

- Feed results back into design process;

- Identify the means of failure detection, isolation and compensation;

- Perform maintainability analysis;

- Document the analysis, summarize uncorrectable design areas, identify special controls necessary to reduce risk;

- Make recommendations;

- Follow up on corrective action implementation / effectiveness.

FMECA may be performed at the functional or piece part level (Lakhoua et al., 2019; Hammouda et al., 2015). Functional FMECA considers the effects of failure at the functional block level, such as a power supply or an amplifier. FMECA considers the effects of individual component failures, such as resistors, transistors, microcircuits, or valves.

The criticality analysis may be quantitative or qualitative, depending on the availability of supporting part failure data.

Strengths of FMECA include its comprehensiveness, the systematic establishment of relationships between failure causes and effects, and its ability to point out individual failure modes for corrective action in design (figure 3). 
DOI: 10.14807/ijmp.v12i2.1249

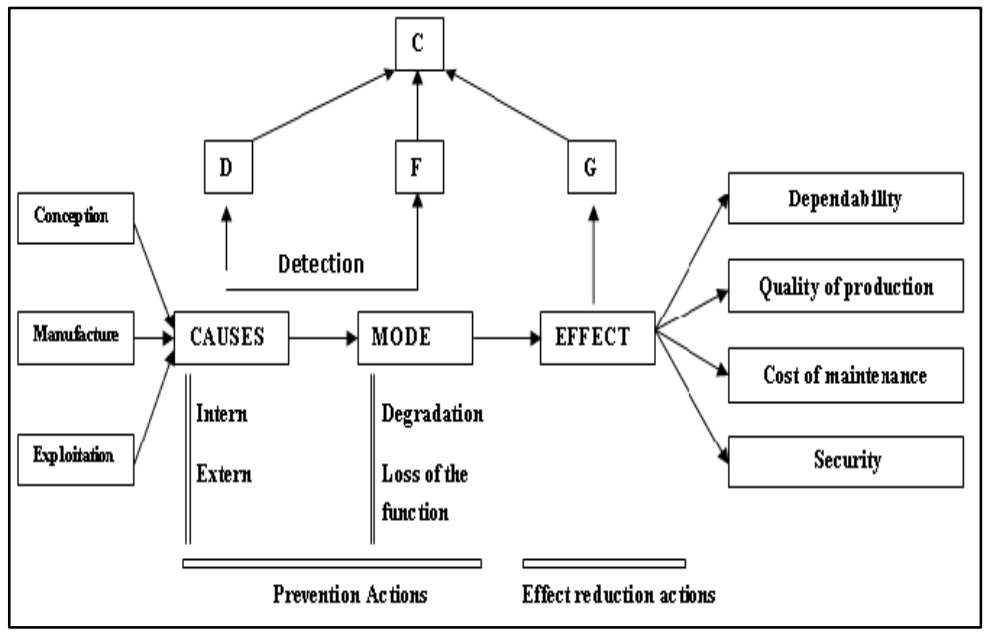

Figure 3: Corrective actions of the FMECA method

Weaknesses include the extensive labour required, the large number of trivial cases considered, and inability to deal with multiple-failure scenarios or unplanned cross-system effects such as sneak circuits.

FMECA is an excellent hazard analysis and risk assessment tool, but it suffers from other limitations. This alternative does not consider combined failures or typically include software and human interaction considerations. It also usually provides an optimistic estimate of reliability. Therefore, FMECA should be used in conjunction with other analytical tools when developing reliability estimates.

The FMECA was presented in some woks in order to analysis medical process in hospital systems (Lakhoua, 2016; Lakhoua, 2018)

According to the figure 3, one notes that exist three corrective action types: prevention actions, actions of preventive detection and actions of effect reductions.

Authors' names and details must not be included anywhere in the article. Instead, a brief autobiographical note (about 100 words) must be supplied, including full name, affiliation, email address and full international contact details, on a separated sheet of paper.

\subsection{Pareto Diagram}

The Pareto diagram prioritizes problems based on the number of occurrences and sets priorities for problem-solving. This tool is based on the law of 20/80. In other words, this tool highlights the $20 \%$ of causes that need to be addressed to solve $80 \%$ of the problem.

It will be useful in determining which levers should be given priority to significantly improve the situation. This tool, relatively simple, makes it possible to present a factual 
DOI: 10.14807/ijmp.v12i2.1249

business problem. Phrases such as "We think the problem comes from", "if we solve this problem it will probably improve" are thus avoided (Pareto, 1965).

The construction steps of the Pareto diagram are: count the observed data; add the number of observations/frequency; rank items in descending order; make the total data; calculate the percentage for each data; calculate the cumulative percentage; chart construction (Piketty, 2013).

\section{ANALYSIS OF THE MAINTENANCE OF THE PACKER MACHINE OF CIGARETTES}

In this part, we will identify the various subsystems and components of the packer machine of cigarette on the basis on the analysis by the graphical tool SADT (Structured Analysis Design Technique), the functional decomposition in order to apply the FMECA method (Failure mode, effects and criticality analysis) and the pareto diagram. This analysis allows us to examine patterns of failures related to each component in order to have the action to be taken.

\subsection{Structured analysis of the packer machine}

The cigarette packaging line has four machines: the packer which ensures the entrance of cigarettes, pack it in 20 and wrap it to get packages; the over wrapper which allows to wrap packages with cellophane paper; the cartridge use which allows to group two packets in 10 interposed, and wrap them in cellophane paper to get a carton of 10 packs. The cartoner which allows grouping 50 cartridges and packing in a carton. Figure 4 shows node A-0 of SADT model of packer machine.

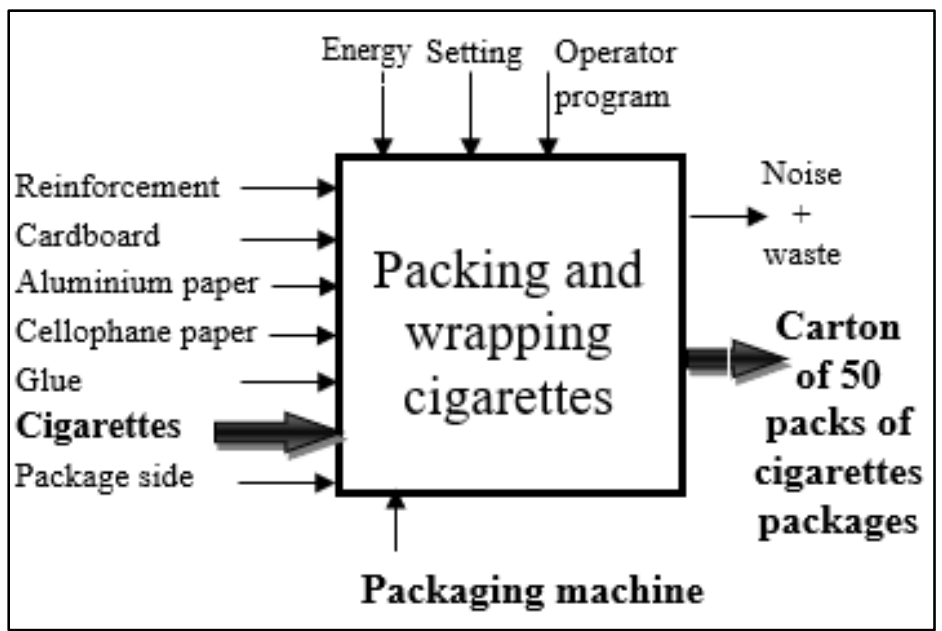

Figure 4: Node A-0 of SADT model of packer machine 
INDEPENDENT JOURNAL OF MANAGEMENT \& PRODUCTION (IJM\&P)

http://www.ijmp.jor.br

v. 12, n. 2, March-April 2021

ISSN: 2236-269X

DOI: 10.14807/ijmp.v12i2.1249

\subsection{FMECA analysis of the packer machine}

In this step we will present the results of the study by describing different modes of failure with its causes and its effects, so the values of the frequency of occurrence of risk, their gravities, their no detection probabilities and their criticalities (Tables 1).

Table 1: FMECA analysis for the electrical cabinet

\begin{tabular}{|c|c|c|c|c|c|c|c|c|c|}
\hline \multirow[t]{2}{*}{ Element } & \multirow[t]{2}{*}{ Function } & \multirow[t]{2}{*}{ Failure mode } & \multirow[t]{2}{*}{ Cause } & \multirow[t]{2}{*}{ Effect } & \multirow[t]{2}{*}{ Detection } & \multicolumn{4}{|c|}{ Criticity } \\
\hline & & & & & & $\mathbf{F}$ & $\mathbf{G}$ & $\mathrm{D}$ & $\mathrm{C}$ \\
\hline Transformer & Adapt the tension & No tension & Shot-circuit & $\begin{array}{l}\text { Machine } \\
\text { stop }\end{array}$ & Voltmeter & 1 & 3 & 3 & 9 \\
\hline Automaton & Manage the system & $\begin{array}{c}\text { Failure an } \\
\text { interface (input } \\
\text { or output) }\end{array}$ & $\begin{array}{l}\text { Failure of } \\
\text { optocoupler }\end{array}$ & $\begin{array}{l}\text { Machine } \\
\text { stop }\end{array}$ & $\begin{array}{l}\text { Automated } \\
\text { detection }\end{array}$ & 1 & 3 & 1 & 3 \\
\hline Breaker & Protect the machine & $\begin{array}{l}\text { The contact } \\
\text { does not close }\end{array}$ & Bad contact & $\begin{array}{l}\text { Machine } \\
\text { not } \\
\text { protected }\end{array}$ & $\begin{array}{c}\text { Visual after } \\
\text { opening }\end{array}$ & 1 & 4 & 3 & 12 \\
\hline Dimmer & Adjust the motor speed & Does not work & $\begin{array}{l}\text { Failure of control } \\
\text { electronics }\end{array}$ & $\begin{array}{l}\text { Motor } \\
\text { stop }\end{array}$ & $\begin{array}{l}\text { Automated } \\
\text { detection }\end{array}$ & 1 & 3 & 1 & 3 \\
\hline \multirow[t]{3}{*}{ Contactor } & \multirow[t]{3}{*}{$\begin{array}{c}\text { Establish or interrupt the } \\
\text { flow of current to the } \\
\text { motor }\end{array}$} & \multirow[t]{3}{*}{ Failure to close } & Coil grilled & \multirow[t]{3}{*}{$\begin{array}{l}\text { Motor } \\
\text { stop }\end{array}$} & \multirow[t]{3}{*}{ Voltmeter } & 1 & 3 & 3 & 9 \\
\hline & & & $\begin{array}{l}\text { Spring stiffness } \\
\text { due to fatigue }\end{array}$ & & & 1 & 3 & 3 & 9 \\
\hline & & & $\begin{array}{c}\text { The contact does } \\
\text { not close due to a } \\
\text { bad contact }\end{array}$ & & & 1 & 2 & 3 & 6 \\
\hline System win 2 & $\begin{array}{c}\text { Adjust the weight of } \\
\text { cigarettes }\end{array}$ & $\begin{array}{c}\text { Data } \\
\text { disappearance }\end{array}$ & Virus & $\begin{array}{l}\text { Cigarette } \\
\text { weight } \\
\text { not } \\
\text { respected }\end{array}$ & Visual & 1 & 3 & 2 & 6 \\
\hline
\end{tabular}

Life of the components of the electrical cabinet follows an exponential distribution (unpredictable failure), and equipment whose life follows an exponential distribution should not be the subject of a preventive maintenance so: the type of maintenance the electrical cabinet needs is corrective maintenance with spare parts availability in store.

Each machine in the packer cigarettes line is studied separately to identify its failures using the FMECA method.

\subsection{Pareto diagram of the packer machine}

A Pareto is performed to target faulty components and thus to be a decision-making tool for the preventive maintenance tasks to be selected 
INDEPENDENT JOURNAL OF MANAGEMENT \& PRODUCTION (IJM\&P)

http://www.ijmp.jor.br

v. 12, n. 2, March-April 2021

ISSN: 2236-269X

DOI: 10.14807/ijmp.v12i2.1249

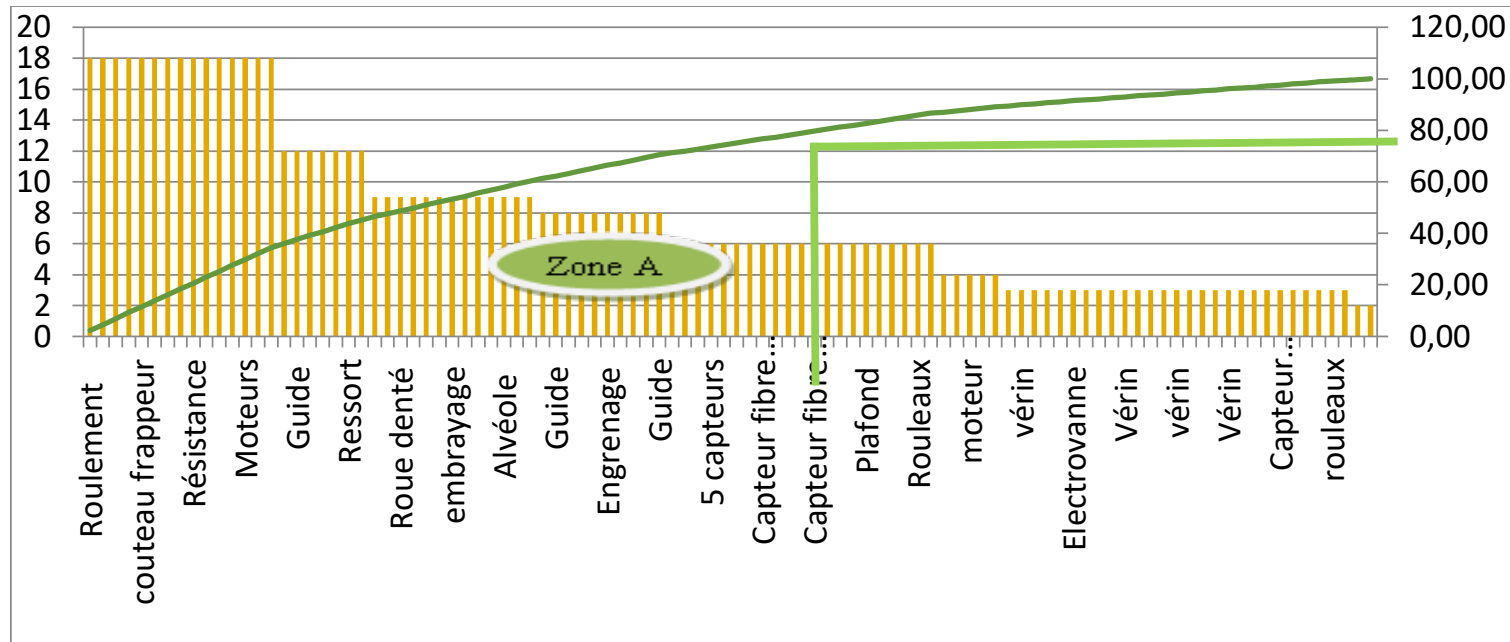

Figure 5: Pareto diagram of the industrial company

As shown in the figure 5: Zone A: $20 \%$ of failures cause $80 \%$ of costs. Zone B: The $30 \%$ more failures cost only 15\% more. Zone C: the remaining $50 \%$ of failures relate to only $5 \%$ of the overall cost. Our priority will be to the failures of Zone A.

In this part, we managed to implement a preventive maintenance plan, available to the maintenance department to improve the rate of return and reduce the cost of corrective maintenance of packer cigarettes line.

\section{CONCLUSION}

During this work, SADT method, FMECA study and Pareto diagram are carried out on a cigarette packer line of a plant in order to improve the maintenance function. Our studies begin with a decomposition of the cigarette packer line based on the functional analysis in order to achieve functional decomposition to identify the components of each machine. Each machine in the chain is studied separately to identify its failures by applying the FMECA method. A Pareto is performed to target faulty components and thus to be a decision-making tool for the preventive maintenance tasks to be selected. This allowed us to propose a set of preventive actions for the most critical components of each equipment on the line.

\section{REFERENCES}

Bareib, P., Marcos, M., \& Vogel-Heuser, B. (2016). A model-based failure recovery approach for automated production systems. IEEE 21st International Conference on Emerging Technologies and Factory Automation (ETFA)., Berlin, Germany.

Bassetto, S. (2005). Contribution à la qualification et amélioration des moyens de production, Thèse, ENSAM.

Buzzatto, L. (1999). Failure mode, effects and criticality analysis (FMECA)., Licensing Process. 
Hammouda, M. B., Lakhoua, M. N., \& Amraoui, L. E. (2015). Dependability Evaluation and Supervision in Thermal Power Plants, International Journal of Electrical and Computer Engineering, 5(5).

Fakhfakh, R., Khanchal, F., Klouz, A., \& Achour, N. (2011). Determinants of tobacco use habits among hospital staff in Tunisia, Preventive Medicine, 52(6), 478-479.

Lakhoua, M. N. (2011). Systemic Analysis of a Wind Power Station in Tunisia, Journal of Electrical and Electronics Engineering, University of Oradea Publisher, 4(1).

Lakhoua, M. N. (2013). Systemic analysis of an industrial system: case study of a grain silo, Arabian Journal for Science and Engineering, Springer Publishing, 38, 1243-1254.

Lakhoua, M. N. (2018). The Need for systemic analysis and design methodology of the medical equipments, International Journal of Applied Systemic Studies, Inderscience, $8(1)$.

Lakhoua, M. N., Hamouda, M. B., Glaa, R. \& Amraoui, L. E. (2016). Contributions to the Analysis and the Supervision of a Thermal Power Plant, International Journal of Advanced Computer Science and Applications, 7(1).

Lakhoua, M. N., \& Karoui, M. F. (2019). Monitoring of a Production System based on Functional and Dysfunctional Analysis, Journal of Computer Science and Control Systems, 12(1).

Lakhoua, M. N., Khanchel, F., Laifi, S., \& Khazemi, S. (2016). System analysis of medical equipment for healthcare management, Annals of the Faculty of Engineering Hunedoara, 14(4), 17.

Lakhoua, M. N., \& Rahmouni, M. (2011). Investigation of the study of the methods of the enterprise modeling, AJBM, 5(16), 6845-6852.

Lakhoua, M. N., Salem, J. B., \& Amraoui, L. E. (2018). The Need for System Analysis based on Two Structured Analysis Methods SADT and SA-RT, Bulletin of Engineering, Fascicule 1.

Malaoui, D., Bettaleb, H., \& Lakhoua, M. N. (2017). Improvement of the Reliability and the Availability of a Production Line, TJASSST.

Marca, D. (2012). SADT/IDEFo for Augmenting UML, Agile and Usability Engineering Methods, in Software and Data Technologies.

Monchy, F. (2015). Maintenance- Outils, Méthodes et Organisations, $4^{\mathrm{e}}$ édition, Dunod, Paris.

Pareto, V. (1965). Essai sur la courbe de la répartition de la richesse, Courbe de répartition de la richesse, Droz, Genève.

Piketty, T. (2013). Le Capital au XXIe siècle, Seuil, Paris.

Rocha, M. (1998). L’écimage-inhibition sur tabac brun, Burley, Virginie, Les cahiers de l'Anitta.

Ross, D. T. (1977). Structured Analysis (SA).: A language for communicating ideas, IEEE Transaction On Software Engineering, 3(1), 16-34.

Saman, B. (2017). Monitoring and Analysis of Microservices Performance, JCSCS, 10(1).

Vari-Kakas, S., \& Poszet, O. (2015). Considerations Regarding the Design and Reliability Analysis of Safety Critical Systems, JCSCS, 8(2). 